\title{
Yield and yield component performances of local pigmented upland rice cultivars from East Nusa Tenggara, Indonesia in three locations
}

\author{
ANTONIUS S. S. NDIWA ${ }^{1, \vartheta}$, YOSEP S. MAU ${ }^{1,2}$ \\ ${ }^{1}$ Department of Agrotechnology, Faculty of Agriculture, Universitas Nusa Cendana. Jl. Adisucipto, Penfui, Kupang 85001, East Nusa Tenggara, \\ Indonesia. Tel./fax.: +62-380-881085, `email: antoniusndiwa@gmail.com \\ ${ }^{2}$ Center of Excellence of Archipelagic Dryland (PUI Lahan Kering Kepualauan), Universitas Nusa Cendana, Jl. Adicuscipto, Penfui-Kupang, NTT 85001 \\ Indonesia. Jl. Adicucipto Penfui-Kupang, Nusa Tenggara Timur, Indonesia.
}

Manuscript received: 20 September 2019. Revision accepted: 24 November 2019.

\begin{abstract}
Ndiwa ASS, Mau YS. 2019. Yield and yield component performances of local pigmented upland rice cultivars from East Nusa Tenggara, Indonesia in three locations. Trop Drylands 3: 49-55. There is increasing demand for pigmented rice due to nutritional benefits, yet the supply is limited. Dryland region in Indonesia, including East Nusa Tenggara Province, has local pigmented upland rice varieties which have been selected based on their agronomic performance, blast resistance, and drought tolerance traits. This study aimed to further elucidate the selected upland rice cultivars for their yield performance and stability in a multi-location trial in three locations. The results showed the significant effect of rice genotype, location, and interactions between rice genotype and location (GxE) on most observed variables, both in each location and across the three locations. Five genotypes produced average grain yield of $\geq 4.0$ t/ha over three locations, i.e., NGR-22, PMK-01, ADN-05, Inpago 7 and Aek Sibundong. These five genotypes were found to produce high and stable grain yield under the three growing environments.
\end{abstract}

Keywords: Colored rice, local cultivar, multi-location, yield stability

\section{INTRODUCTION}

Pigmented rice, such as red and black rice, has become increasingly popular in the last decades due to its considerable benefits as functional, healthy foods. Red and black rice contain high carbohydrates and also a substantial amount of protein, vitamin, mineral, and anthocyanin contents, all of which are regarded as health-promoting properties. The high anthocyanin content of red and black rice can serve as antioxidants (Satue-Gracia 1997; AbdelAal et al. 2006; Nam et al. 2006), anti-inflammatory (Tsuda et al. 2002) and anti-cancer (Hyun et al. 2004; Zhao et al. 2004). All these advantageous properties drive the increasing demand of pigmented rice while their availability in the market is still scarce (Badan Litbang Pertanian 2012).

The existing red and black rice superior varieties in Indonesia is lacking. Only a few superior varieties have been released until 2012, i.e., red rice varieties Bahbutong and Aek Sibundong (Santika and Rozakurniati 2010) and Mandel Handayani and Segreng Handayani (Departemen Pertanian 2009a, b), all of which are superior local varieties. The most recently released improved varieties included Inpari 24, Inpago 7, and Inpago Unram 1 (Badan Litbang Pertanian 2012); the former is a lowland variety while the last two are upland rice varieties. There is no released variety of black rice at the moment.

The limited number of red and black rice superior varieties (Badan Litbang Pertanian 2012) needs to be addressed to anticipate the increasing demand of this rice. Selection of local germplasm is an easier and faster way of handling this problem as local germplasm is abundantly available and easily accessed by the farmers (Mau et al. 2018). Besides, the selection of local germplasm promotes the use of these local resources and prevents them from extinction. Local superior germplasm can also be used as the parental source in hybridization programs to produce new superior varieties.

Pigmented upland rice germplasm from East Nusa Tenggara (Nusa Tenggara Timur/NTT) Province had been characterized for their genetic diversity (Mau et al. 2017) and also evaluated for their resistance to blast disease (Mau et al. 2018) and tolerance to drought (Mau et al. 2019) which resulted in several promising cultivars being selected. These selected cultivars have high grain yield potential, are resistant to blast disease, and are tolerant to drought, thus, they are highly promising to be further tested in multi-environment conditions to select for cultivars having high and stable yield. This study aimed to evaluate yield performance of red and black upland rice cultivars from NTT Province across multi-environment conditions, and to select cultivars that produce high and stable yields.

\section{MATERIALS AND METHODS}

\section{Research location and materials}

This research was conducted in three locations covering the low to medium altitude in East Nusa Tenggara (NTT) Province, Indonesia from April to October 2018. The general descriptions of the three research locations are presented in Table 1. Plant materials used in the study were local pigmented rice accessions from East Nusa Tenggara Province and check varieties. 
Table 1. General descriptions of the research locations in East Nusa Tenggara Province

\begin{tabular}{llll}
\hline Location & District & Altitude (m. asl) & Physical characteristic \\
\hline Oerinbesi & Timur Tengah Utara & 360 & Dryland, Grumosol soil type \\
Penfui & Kupang & 100 & Dryland, Inceptisol soil type \\
Honihama & Flores Timur & 50 & Dryland, Alvisol soil type \\
\hline
\end{tabular}

\section{Research design and procedures}

A Randomized Block Design was employed in each research site, consisting of 15 rice genotypes as treatment, which comprised of local cultivars, i.e. four red rice (ADN04, ISN-02, SBD-04, HK-07) and eight black rice (ADN03, ADN-05, HK-06, KMD-01, MGP-01, NGR-22, PMK01, WTN-22), and two check red rice varieties (INPAGO 7, Aek Sibundong) and one advanced line of black rice (Aks-Htm-12). The check varieties were kindly provided by Indonesian Rice Research Institute, Sukamandi. The advanced line of black rice was provided by Dr. Buang Abdullah (personal communication) from Indonesian Rice Research Institute, Muara, Bogor.

Rice seeds were planted in trial plots, each measuring $1.5 \mathrm{~m} \times 1.5 \mathrm{~m}$ at a planting distance of $25 \mathrm{~cm} \times 20 \mathrm{~cm}$. The planting was done directly into the planting hole. Each planting hole was planted with two seeds, and only one plant was retained until harvest. Fertilization was carried out with a compound NPK fertilizer $(16: 16: 16)$ at a dosage of $56.25 \mathrm{~g} \mathrm{plot}^{-1}$ or equivalent to $500 \mathrm{~kg} \mathrm{ha}^{-1}$. Fertilization was done twice at the time of planting and at 45 days after planting. Weeds were discarded manually from the planting plots. Irrigation was provided daily to maintain field capacity levels. The main pests attacking the crops were birds and rice bugs. The former was controlled manually by driving them out from the rice fields while the latter was controlled by using chemical spray (Decis 25 EC).

\section{Observation and data analysis}

The observed variables included plant height at harvest, number of panicles per plant, harvesting date, and grain yield per plot, which was then converted to yield per hectare.

One-way ANOVA was performed on data obtained from each location. Bartlett test of homogeneity of variance was performed on data collected from the three sites. Data from the three sites with homogeneous variance were further subjected to the combined analysis of variance to see the effect of genotype by location interaction and yield stability.

\section{RESULTS AND DISCUSSION}

\section{Results}

ANOVA results revealed a highly significant difference $(\mathrm{P}<0.01)$ amongst rice genotypes in each location. This indicated that the tested pigmented upland rice cultivars are highly diverse in the observed variables in each of the three locations. Bartlett test revealed that variances of productive tillers/panicle numbers across the three locations were nonhomogeneous $(\mathrm{P}>0.05)$. Error variances of harvesting date, plant height at harvest, panicle number per plant and grain yield per plot variables were homogeneous, thus, they were further subjected to combined analysis of variance. Means of panicle number per plant, plant height at harvest, harvesting date, and grain yield of tested rice genotypes are presented in Tables 2, 3, 4 and 5, respectively.

\section{Number of panicle per plant}

Error variances of panicle number per plant over three locations were heterogeneous, thus, combined analysis of variance was not performed on this variable. Instead, the mean panicle number per plant in each location was separately subjected to one-way ANOVA and presented in Table 2. Across the three research sites, the number of panicle or productive tillers averaged 4.25-19.9 panicles per plant; WTN-022 showed the highest panicle number followed by KMD-01. These two local cultivars consistently produced the highest number of panicles at three test sites and were not significantly different from Aek Sibundong in Flores Timur. The changes in the ranking of panicle number per plant across the three test locations indicate that each test location has different agroclimatic conditions such as soil fertility, temperature, humidity, etc., and each rice genotype has different responses to variations in the environmental conditions.

WTN-022, KMD-01, and Aek Sibundong could produce a large number of panicles per plant in the three locations. On average across the three locations, high panicle number per plant was observed in two local cultivars KMD-01 (18.05 panicles) and WTN-22 (19.90 panicles), and the check variety Aek Sibundong (14.85 panicles). The rest ten local cultivars produced low number of panicles per plant ranging from $4.43-10.70$ panicles per plant. The average number of panicles per plant in the three locations was 10.2, 8.24 and 9.47 for Kupang, Flores Timur, and Timor Tengah Utara, respectively.

The local cultivars KMD-01 and WTN-02 consistently produced higher panicle number per plant in two locations, i.e. Kupang ( 23.5 and 25 panicles, respectively) and Timor Tengah Utara (18 and 19.9 panicles, respectively) but produced a lower panicle number in Flores Timur (12.6 and 14.8 panicles, respectively). Meanwhile, the check variety Aek Sibundong consistently produced almost similar panicle numbers per plant in the three locations, respectively, $15.50,14.20$, and 14.85 panicles. 
Table 2. Mean panicle number per plant of pigmented rice cultivars from NTT Province in three locations

\begin{tabular}{|c|c|c|c|c|}
\hline \multirow{2}{*}{ Genotype code $(G)$} & \multicolumn{3}{|c|}{ Location/district (E) } & \multirow{2}{*}{ Mean (G) } \\
\hline & Kupang & Flores Timur & Timor Tengah Utara & \\
\hline $\mathrm{ADN}-03$ & $8.00 \quad a b c$ & $5.40 \quad \mathrm{abc}$ & $6.70 \quad$ abcd & 6.70 \\
\hline ADN-04 & $3.50 \quad \mathrm{a}$ & 5.00 & 4.25 & 4.25 \\
\hline ADN-05 & $5.00 \mathrm{abc}$ & 8.90 & abcd & 6.95 \\
\hline HK-06 & $4.00 \quad \mathrm{ab}$ & 4.60 & 4.30 & 4.30 \\
\hline HK-07 & 7.00 & 2.50 & 4.75 & 4.75 \\
\hline KMD-01 & 23.50 & 12.60 & 18.05 & 18.05 \\
\hline ISN-02 & 7.00 & 9.60 & 8.30 & 8.30 \\
\hline MGP-01 & abcd & 3.80 & 6.40 & 6.40 \\
\hline NGR-22 & 11.00 & 4.80 & abcd & 7.90 \\
\hline PMK-01 & 11.50 & 9.50 & 10.50 & 10.50 \\
\hline SBD-04 & 10.50 & 10.90 & 10.70 & 10.70 \\
\hline WTN-22 & 25.00 & 14.80 & 19.90 & 19.90 \\
\hline INPAGO 7 & 10.50 & 8.30 & 9.40 & 9.40 \\
\hline Aks-Htm-12 & 9.50 & 8.70 & 9.10 & 9.10 \\
\hline Aek Sibundong & 15.50 & 14.20 & 14.85 & 14.85 \\
\hline Mean $(E)$ & 10.2 & 8.24 & 9.47 & \\
\hline
\end{tabular}

Note: Numbers followed by the same lowercase within the same column are not significantly different by post hoc DMRT (0.05).

Table 3. Mean plant height of pigmented rice cultivars from NTT Province in three locations (all values are in $\mathrm{cm}$ ).

\begin{tabular}{|c|c|c|c|c|c|c|c|c|}
\hline \multirow{4}{*}{$\begin{array}{l}\text { Genotype code (G) } \\
\text { ADN-03 }\end{array}$} & \multicolumn{6}{|c|}{ Location/district (E) } & \multirow{2}{*}{\multicolumn{2}{|c|}{ Mean (G) }} \\
\hline & \multicolumn{2}{|c|}{ Kupang } & \multicolumn{2}{|c|}{ Flores Timur } & \multicolumn{2}{|c|}{ Timor Tengah Utara } & & \\
\hline & 141.50 & e & 116.90 & ef & 129.20 & $\mathrm{i}$ & \multirow[t]{2}{*}{129.20} & \multirow[t]{2}{*}{$\mathrm{h}$} \\
\hline & $\mathrm{C}$ & & $\mathrm{A}$ & & B & & & \\
\hline \multirow[t]{2}{*}{$\mathrm{ADN}-04$} & 130.00 & d & 107.80 & de & 118.90 & fgh & 118.90 & efgh \\
\hline & $\mathrm{C}$ & & A & & B & & & \\
\hline \multirow[t]{2}{*}{ ADN-05 } & 125.50 & d & 124.80 & $\mathrm{f}$ & 125.15 & hi & 125.15 & gh \\
\hline & A & & $\mathrm{A}$ & & $\mathrm{A}$ & & & \\
\hline \multirow[t]{2}{*}{ HK-06 } & 120.00 & d & 117.30 & ef & 118.65 & fgh & 118.65 & efgh \\
\hline & A & & A & & A & & & \\
\hline \multirow[t]{2}{*}{ HK-07 } & 127.00 & d & 107.30 & de & 117.15 & fgh & 117.15 & efg \\
\hline & $\mathrm{C}$ & & A & & B & & & \\
\hline \multirow[t]{2}{*}{ KMD-01 } & 76.25 & $a b$ & 69.20 & $\mathrm{a}$ & 72.73 & $\mathrm{a}$ & 72.73 & $\mathrm{a}$ \\
\hline & A & & A & & A & & & \\
\hline \multirow[t]{2}{*}{ ISN-02 } & 125.50 & d & 116.20 & ef & 120.85 & ghi & 120.85 & fgh \\
\hline & A & & A & & A & & & \\
\hline \multirow[t]{2}{*}{ MGP-01 } & 122.00 & d & 108.80 & de & 115.40 & fg & 115.40 & efg \\
\hline & B & & A & & $\mathrm{AB}$ & & & \\
\hline \multirow[t]{2}{*}{ NGR-22 } & 95.00 & $\mathrm{c}$ & 88.20 & $\mathrm{~b}$ & 91.60 & $\mathrm{bc}$ & 91.60 & $\mathrm{bc}$ \\
\hline & A & & A & & A & & & \\
\hline \multirow[t]{2}{*}{ PMK-01 } & 97.50 & $\mathrm{c}$ & 105.40 & $\mathrm{~cd}$ & 101.45 & de & 101.45 & $\mathrm{~cd}$ \\
\hline & A & & A & & A & & & \\
\hline \multirow[t]{2}{*}{ SBD-04 } & 99.5 & $\mathrm{c}$ & 96.60 & $\mathrm{bc}$ & 97.98 & $\mathrm{~cd}$ & 97.98 & $\mathrm{~cd}$ \\
\hline & A & & A & & A & & & \\
\hline \multirow[t]{2}{*}{ WTN-22 } & 84.25 & $\mathrm{~b}$ & 86.80 & $\mathrm{~b}$ & 85.53 & $\mathrm{~b}$ & 85.53 & $\mathrm{~b}$ \\
\hline & A & & A & & A & & & \\
\hline \multirow[t]{2}{*}{ INPAGO 7} & 105.60 & $\mathrm{c}$ & 111.20 & de & 108.40 & ef & 108.40 & de \\
\hline & A & & A & & A & & & \\
\hline \multirow[t]{2}{*}{ Aks-Htm-12 } & 102.50 & $\mathrm{c}$ & 123.20 & $\mathrm{f}$ & 112.85 & fg & 112.85 & ef \\
\hline & A & & $\mathrm{C}$ & & B & & & \\
\hline \multirow[t]{2}{*}{ Aek Sibundong } & 68.50 & $\mathrm{a}$ & 69.00 & $\mathrm{a}$ & 68.75 & $\mathrm{a}$ & 68.75 & $\mathrm{a}$ \\
\hline & A & & A & & A & & & \\
\hline Mean (E) & 108.03 & $\mathrm{C}$ & 103.25 & A & 105.64 & B & & \\
\hline
\end{tabular}

Note: Numbers followed by the same letter (s) are not significantly different by post hoc DMRT (0.05). Uppercase indicates comparison within the same row while lowercase indicates comparison within the same column 


\section{Plant height at harvest}

Combined analysis of variance showed that location, pigmented upland rice genotype, genotype by location/environmental interaction $(\mathrm{GxE})$ had a significant $(\mathrm{P}<0.01)$ effect on plant height at harvest. This indicates that variation of plant height at harvest among the pigmented upland rice genotypes did not occur only within the same location but also between locations. There were changes in the ranking of harvesting date of the rice genotypes over the three sites as an indication of genotype by location interaction.

Over the three locations, plant height at harvest ranged from $68.75 \mathrm{~cm}$ to $129.15 \mathrm{~cm}$. Aek Sibundong $(68.75 \mathrm{~cm})$ had the shortest plant height across the three locations, but was not significantly different from KMD-01 $(72.73 \mathrm{~cm})$, which indicates that shorter plant height of these two genotypes was genetically controlled. Meanwhile, the highest plant height was observed in ADN-03 (129.15 cm), which did not differ from ADN-04 $(118.90 \mathrm{~cm}), \mathrm{ADN}-05$ $(125.15 \mathrm{~cm})$, HK-06 $(118.65 \mathrm{~cm})$, and ISN-02 $(120.85 \mathrm{~cm})$. These local cultivars were also the tallest plant when grown in at least two of the three test sites, indicating the effect of genetic control on the plant height.

\section{Harvesting date}

Combined analysis of variance showed that location caused no significant effect on harvesting date but rice genotype, genotype by location/environmental interaction (GxE) had a significant $(\mathrm{P}<0.01)$ effect on harvesting date. This indicates that variation of harvesting date did occur among rice genotypes and the magnitude of the changes is depending on the location. Changes in the ranking of harvesting date of the rice genotypes over the three sites indicate significant genotype by location interaction effect.

Table 4. Mean harvesting date (days after planting) of pigmented rice cultivars from NTT Province in three locations

\begin{tabular}{|c|c|c|c|c|c|c|c|c|}
\hline \multirow{4}{*}{$\begin{array}{l}\text { Genotype code }(\mathbf{G}) \\
\text { ADN-03 }\end{array}$} & \multicolumn{6}{|c|}{ Location/district (E) } & \multirow{2}{*}{\multicolumn{2}{|c|}{ Mean $(G)$}} \\
\hline & \multicolumn{2}{|c|}{ Kupang } & \multicolumn{2}{|c|}{ Flores Timur } & \multicolumn{2}{|c|}{ Timor Tengah Utara } & & \\
\hline & 135.50 & $\mathrm{~b}$ & 141.00 & $\mathrm{c}$ & 138.50 & def & \multirow[t]{2}{*}{138.33} & \multirow[t]{2}{*}{$\mathrm{cd}$} \\
\hline & $\mathrm{A}$ & & $\mathrm{A}$ & & $\mathrm{AB}$ & & & \\
\hline \multirow[t]{2}{*}{$\mathrm{ADN}-04$} & 128.50 & $\mathrm{a}$ & 142.00 & $\mathrm{~cd}$ & 135.50 & $\mathrm{~cd}$ & 135.33 & $\mathrm{bc}$ \\
\hline & A & & $\mathrm{C}$ & & B & & & \\
\hline \multirow[t]{2}{*}{$\mathrm{ADN}-05$} & 129.50 & $\mathrm{a}$ & 142.50 & $\mathrm{~cd}$ & 136.00 & $\mathrm{~cd}$ & 136.00 & $\mathrm{bc}$ \\
\hline & A & & $\mathrm{C}$ & & B & & & \\
\hline \multirow[t]{2}{*}{ HK-06 } & 131.00 & $\mathrm{a}$ & 142.50 & $\mathrm{~cd}$ & 137.00 & cde & 136.83 & $\mathrm{bc}$ \\
\hline & $\mathrm{A}$ & & $\mathrm{C}$ & & B & & & \\
\hline \multirow[t]{2}{*}{ HK-07 } & 143.50 & d & 153.00 & e & 148.50 & g & 148.33 & d \\
\hline & $\mathrm{A}$ & & $\mathrm{C}$ & & B & & & \\
\hline \multirow[t]{2}{*}{ KMD-01 } & 130.50 & $\mathrm{a}$ & 136.00 & $\mathrm{~b}$ & 133.50 & $\mathrm{bc}$ & 133.33 & $\mathrm{abc}$ \\
\hline & $\mathrm{A}$ & & B & & $\mathrm{AB}$ & & & \\
\hline \multirow[t]{2}{*}{ ISN-02 } & 129.00 & $\mathrm{a}$ & 122.50 & $\mathrm{a}$ & 126.00 & $\mathrm{a}$ & 125.83 & $a b$ \\
\hline & B & & $\mathrm{A}$ & & $\mathrm{B}$ & & & \\
\hline \multirow[t]{2}{*}{ MGP-01 } & 148.00 & $\mathrm{e}$ & 148.50 & $\mathrm{~d}$ & 148.50 & $\mathrm{~g}$ & 148.33 & $\mathrm{~d}$ \\
\hline & $\mathrm{A}$ & & $\mathrm{A}$ & & $\mathrm{A}$ & & & \\
\hline \multirow[t]{2}{*}{ NGR-22 } & 130,50 & $\mathrm{a}$ & 145,00 & $\mathrm{c}$ & 138,00 & def & 137.83 & $\mathrm{~cd}$ \\
\hline & $\mathrm{A}$ & & $\mathrm{C}$ & & B & & & \\
\hline \multirow[t]{2}{*}{ PMK-01 } & 128.50 & $\mathrm{a}$ & 120.00 & $\mathrm{a}$ & 124.50 & $\mathrm{a}$ & 124.33 & $\mathrm{a}$ \\
\hline & $\mathrm{C}$ & & $\mathrm{A}$ & & B & & & \\
\hline \multirow[t]{2}{*}{ SBD-04 } & 146.50 & de & 134.50 & $\mathrm{~b}$ & 141.00 & $\mathrm{f}$ & 140.67 & $\mathrm{~cd}$ \\
\hline & $\mathrm{C}$ & & $\mathrm{A}$ & & B & & & \\
\hline \multirow[t]{2}{*}{ WTN-22 } & 140.00 & $\mathrm{c}$ & 122.50 & $\mathrm{a}$ & 131.50 & $\mathrm{~b}$ & 131.33 & $a b c$ \\
\hline & $\mathrm{C}$ & & A & & B & & & \\
\hline \multirow[t]{2}{*}{ INPAGO 7} & 144.50 & de & 135.00 & $\mathrm{~b}$ & 140.00 & ef & 139.83 & $\mathrm{~cd}$ \\
\hline & $\mathrm{C}$ & & $\mathrm{A}$ & & B & & & \\
\hline \multirow[t]{2}{*}{ Aks-Htm-12 } & 138.50 & $\mathrm{bc}$ & 122.50 & $\mathrm{a}$ & 131.00 & $\mathrm{~b}$ & 130.67 & $a b c$ \\
\hline & C & & A & & B & & & \\
\hline \multirow[t]{2}{*}{ Aek Sibundong } & 129.00 & $\mathrm{a}$ & 119.50 & $\mathrm{a}$ & 124.50 & $\mathrm{a}$ & 124.33 & $\mathrm{a}$ \\
\hline & $\mathrm{C}$ & & $\mathrm{A}$ & & B & & & \\
\hline Mean $(E)$ & 135.53 & A & 135.13 & A & 135.60 & A & & \\
\hline
\end{tabular}


Table 5. Mean grain yield plot $^{-1}\left(1 \mathrm{~m}^{2}\right)(\mathrm{g})$ of pigmented rice cultivars from NTT Province in three locations.

\begin{tabular}{|c|c|c|c|c|c|c|c|c|}
\hline \multirow{4}{*}{$\begin{array}{l}\text { Genotype code }(\mathbf{G}) \\
\mathrm{ADN}-03\end{array}$} & \multicolumn{6}{|c|}{ Location/district (E) } & \multirow{2}{*}{\multicolumn{2}{|c|}{ Mean (G) }} \\
\hline & \multicolumn{2}{|c|}{ Kupang } & \multicolumn{2}{|c|}{ Flores Timur } & \multicolumn{2}{|c|}{ Timor Tengah Utara } & & \\
\hline & 380.40 & fg & 419.35 & $\mathrm{e}$ & 391.88 & $\mathrm{~d}$ & \multirow[t]{2}{*}{397.21} & \multirow[t]{2}{*}{$\mathrm{e}$} \\
\hline & A & & A & & $\mathrm{A}$ & & & \\
\hline \multirow[t]{2}{*}{ ADN-04 } & 319.75 & de & 425.60 & $\mathrm{e}$ & 407.68 & $d$ & 384.34 & $\mathrm{e}$ \\
\hline & $\mathrm{A}$ & & B & & B & & & \\
\hline \multirow[t]{2}{*}{ ADN-05 } & 367.15 & $\mathrm{f}$ & 415.40 & $\mathrm{e}$ & 417.03 & $\mathrm{~d}$ & 399.86 & $\mathrm{e}$ \\
\hline & $\mathrm{A}$ & & B & & B & & & \\
\hline \multirow[t]{2}{*}{ HK-06 } & 288.50 & $\mathrm{~d}$ & 415.90 & $\mathrm{e}$ & 307.20 & $\mathrm{c}$ & 337.20 & d \\
\hline & A & & B & & $\mathrm{A}$ & & & \\
\hline \multirow[t]{2}{*}{ HK-07 } & 284.70 & $\mathrm{~d}$ & 355.70 & $\mathrm{~d}$ & 320.20 & $\mathrm{c}$ & 320.20 & $\mathrm{~d}$ \\
\hline & $\mathrm{A}$ & & B & & $\mathrm{AB}$ & & & \\
\hline \multirow[t]{2}{*}{ KMD-01 } & 241.00 & $\mathrm{c}$ & 291.00 & $\mathrm{c}$ & 256.00 & $\mathrm{~b}$ & 262.67 & $\mathrm{c}$ \\
\hline & $\mathrm{A}$ & & B & & $\mathrm{AB}$ & & & \\
\hline \multirow[t]{2}{*}{ ISN-02 } & 175.50 & b & 226.00 & $\mathrm{~b}$ & 250.75 & b & 217.42 & b \\
\hline & $\mathrm{A}$ & & B & & B & & & \\
\hline \multirow[t]{2}{*}{ MGP-01 } & 114.25 & $\mathrm{a}$ & 163.60 & $\mathrm{a}$ & 138.93 & $\mathrm{a}$ & 138.93 & $\mathrm{a}$ \\
\hline & A & & B & & $\mathrm{AB}$ & & & \\
\hline \multirow[t]{2}{*}{ NGR-22 } & 453.50 & $\mathrm{~h}$ & 543.05 & $\mathrm{f}$ & 482.68 & $\mathrm{e}$ & 493.08 & $\mathrm{f}$ \\
\hline & A & & B & & A & & & \\
\hline \multirow[t]{2}{*}{ PMK-01 } & 449.50 & $\mathrm{~h}$ & 514.60 & $\mathrm{f}$ & 469.50 & $\mathrm{e}$ & 477.87 & $\mathrm{f}$ \\
\hline & A & & A & & A & & & \\
\hline \multirow[t]{2}{*}{ SBD-04 } & 353.90 & ef & 413.90 & $\mathrm{e}$ & 403.90 & d & 390.57 & $\mathrm{e}$ \\
\hline & A & & B & & B & & & \\
\hline \multirow[t]{2}{*}{ WTN-22 } & 346.90 & ef & 331.90 & $\mathrm{~d}$ & 339.40 & $\mathrm{c}$ & 339.40 & $\mathrm{~d}$ \\
\hline & A & & A & & A & & & \\
\hline \multirow[t]{2}{*}{ INPAGO 7} & 418.70 & gh & 513.85 & $\mathrm{f}$ & 465.28 & $\mathrm{e}$ & 465.94 & $\mathrm{f}$ \\
\hline & A & & $\mathrm{C}$ & & B & & & \\
\hline \multirow[t]{2}{*}{ Aks-Htm-12 } & 314.10 & de & 340.90 & $\mathrm{~d}$ & 320.00 & $\mathrm{c}$ & 325.00 & d \\
\hline & A & & A & & $\mathrm{A}$ & & & \\
\hline \multirow[t]{2}{*}{ Aek Sibundong } & 412.20 & gh & 431.75 & $\mathrm{e}$ & 414.48 & $\mathrm{~d}$ & 419.48 & $\mathrm{e}$ \\
\hline & A & & A & & A & & & \\
\hline Mean (EL) & 328.00 & A & 386.83 & $\mathrm{C}$ & 358.99 & B & & \\
\hline
\end{tabular}

Note: Numbers followed by the same letter (s) are not significantly different by post hoc DMRT (0.05). Uppercase indicates comparison within the same row while lowercase indicates comparison within the same column

The mean harvesting dates in Kupang, Flores Timur, and Timor Tengah Utara were insignificant, respectively, 135.53, 135.13, and 135.60 days after planting. Across the three locations, mean harvesting date of the tested rice genotypes ranged from 124 days after planting (DAP) (PMK-01 and Aek Sibundong) to 148 DAP (MGP-01 and HK-07). In Kupang location, the shortest harvesting date (128 DAP) was observed in PMK-01 and ADN-04, but was not significantly different from that of Aek Sibundong, ADN-05, ISN-02, KMD-01, NGR-22 (129-131 DAP). The longest harvesting time in Kupang was observed in HK-07 and MGP-01 (143-148 DAP). Aek Sibundong has harvested the fastest (119 DAP) in Flores Timur and was not significantly different from local accessions PMK-01, WTN-22, Aks-Htm-12 and ISN-02 (120-122 DAP). Local accessions PMK-01 and MAU-02 (124 DAP) were harvested earlier in TTU location. MGP-01 and HK-07 were harvested the last in the three locations with average 148 DAP. Thus, it can be said that genetic factors are very dominant in determining the harvesting date in three growing locations.

\section{Grain yield}

Combined analysis of variance showed that the location and pigmented upland rice genotype by location interaction had a significant effect $(\mathrm{P}<0.01)$ on grain weight plot $^{-1}$. This indicates a variation in grain weight plot $^{-1}$ among upland rice genotypes within each location and across the three locations. Variations in grain yield plot $^{-1}$ might have occurred due to differences in genetic factors and their responses to changes in agro-climate environment conditions in the three locations.

The average grain weight plot $^{-1}$ presented in Table 5 shows that, across the three test sites, mean grain weight per plot ranged between $139 \mathrm{~g}$ (MGP-01) and $493 \mathrm{~g}$ (NGR22 ) or equals to $1.39-4.93 \mathrm{t} \mathrm{ha}^{-1}$. NGR-022 produced the highest grain yield in each of the three locations (453-543 $\mathrm{g}$ plot $^{-1}$, equivalent to 4.53-5.43 $\left.\mathrm{t} \mathrm{ha}^{-1}\right)$, but not significantly different from PMK-01 (449 - $514 \mathrm{~g}$ equals to 4.49-5.14 t $\left.\mathrm{ha}^{-1}\right)$ and the check variety Inpago 7 (418-513 g equals to 4.18-5.13 $\left.\mathrm{t} \mathrm{ha}^{-1}\right)$. This indicates that these cultivars have high yield potential in the dryland conditions of NTT Province during the dry season. 


\section{Discussion}

The present study results (Table 2) revealed variation in panicle number per plant across the three test locations, indicating that each test location has different agro-climatic conditions, such as soil fertility, temperature, humidity, etc., and each rice genotype has different responses to variations in the environmental conditions. The number of panicles per plant, according to Sunihardi et al. (2004), can be classified into four groups, i.e., low (9-11 panicles), moderate (12-14 panicles), high (15-20 panicles) and very high ( $>20$ panicles). Based on these criteria, the number of panicles of the tested red and black upland rice varieties from NTT Province ranged between low to high categories.

Plant height of the tested rice genotypes was significantly affected by genotype by locations, which means that the genotypes had variation in plant height when they were planted in different locations. The check variety Aek Sibundong had the shortest plant height (68.75 $\mathrm{cm}$ ) across the three locations, but was not significantly different from local cultivar KMD-01 $(72.73 \mathrm{~cm})$, indicating that shorter plant height of these two genotypes was genetically controlled. According to Suparyono dan Setyono (1993), short plant height is one of preferable traits of rice since this trait can prevent the rice plant from lodging caused by extreme weather conditions such as heavy rain and wind. Siregar et al. (2003) explained that plant height is related to photosynthesis process. Shorter plants absorb more sunlight as compared to the taller ones, since the sunlight more easily penetrates their canopies. Such two advantages of short plant height are supposed to be responsible for higher yield of most superior varieties (Yoshida 1981).

Mean harvesting dates of tested rice genotypes across the three locations ranged from 124.22-148.33 days after planting, which are, in general, classified as medium to late maturity based on the harvesting date category for rice, i.e., a) short maturity: 100-115 days, b) medium maturity: 116125 days, and c) late maturity: 126-150 days (Siregar et al. 2013). Only three genotypes were medium maturing genotypes, i.e. ISN-02, PMK-01, and Aek Sibundong while the rest were late maturing genotypes. Genotypes with low to medium maturity types are more suitable for dryland areas with short rainy seasons such as East Nusa Tenggara Province, which has only about 3-4 months of rain during a year.

Table 5 shows variation in grain yield and also a slight change in the ranking of the genotypes in different locations. This indicates the existence of the effect of upland rice genotype by environmental interaction. From plant breeding perspective, the presence of genotype by environment interaction indicates specific adaptation. However, data in Table 5 also show that several rice cultivars (NGR-022, PMK-01, INPAGO7, and Aek Sibundong) produce consistently high grain yield irrespective of the change of environment/location. This shows that these rice genotypes have wide adaptability and yield stability in diverse agro-climate conditions (Yan and Kang 2003; Baafi and Safo-Kantanka 2008). Rice genotype with stable yield under various environments shows wide adaptability. The two local cultivars NGR-022 and PMK-
01 had also been found to be drought tolerant and high yielding in an earlier study by Mau et al. (2019). Thus, the local red and black upland rice cultivars from NTT; NGR22 and PMK-01 can be used as the parental source for the generation of new superior varieties or can be directly proposed as local superior varieties with stable and high yield.

In conclusion, the present study results showed genotype by location interaction effect on all observed variables except for the number of panicles per plant. Five genotypes were found to produce an average grain yield of $\geq 4.0 \mathrm{t} \mathrm{ha}^{-1}$ in the three locations, i.e., NGR-022, PMK-01, ADN-05, Inpago 7 and Aek Sibundong. These rice genotypes produced high and stable yields, and thus, have wide adaptability to environmental conditions of East Nusa Tenggara Province. Thus, they can be used as parental sources for generation of new superior varieties and, the local cultivars can be directly proposed as superior varieties with specific adaptation for environmental conditions of East Nusa Tenggara Province.

\section{ACKNOWLEDGEMENTS}

This research was supported financially by the Indonesian Ministry of Research, Technology and Higher Education through Penelitian Terapan Unggulan Perguruan Tinggi research scheme, 2018 (Contract Number 135/UN15.19/LT/2018). Special thanks to Dr. Buang Abdulah for providing us with provided an advanced line of black rice as a check variety. Thanks are addressed to Trivonianus Payong Kenotan, Yuferty Neolaka, and Yohanes Hendra Padi for technical support in the fields.

\section{REFERENCES}

Abdel-Aal E-SM, Young J, Rabalsk I. 2006. Anthocyanin composition in black, blue, pink, purple, and red cereal grains. J Agric Food Chem 54: 4696-4704. DOI: 10.1021/jf0606609

Baafi E, Safo-Kantanka O. 2008. Agronomic evaluation of some local elite and released cassava varieties in the forest and traditional ecozones of Ghana. Asian J Agric Res 2 (1): 32-36. DOI: 10.3923/ajar.2008.32.36

Satue-Gracia M, Heinonen IM, Frankel EN. 1997. Anthocyanins as antioxidants on human low-density lipoprotein and lecithin liposome systems. J Agric Food Chem 45: 3362-3367. DOI: 10.1021/jf970234a

Nam SH, Choi SP, Kang MY, Koh HJ, Kozukue N, Friedman M. 2006. Antioxidative activities of bran from twenty-one pigmented rice cultivars. Food Chem 94: 613-620. DOI: 10.1016/j.foodchem.2004.12.010

Tsuda T, Horio F, Osawa T. 2002. Cyanidin 3-O-â-glucoside suppresses nitric oxide production during a zymosan treatment in rats. J Nutr Sci Vitaminol 48: 305-310. DOI: $10.3177 /$ jnsv.48.305

Zhao C, Giusti MM, Malik M, Moyer MP, Magnuson BA. 2004. Effects of commercial anthocyanin-rich extracts on colonic cancer and nontumorigenic colonic cell growth. J Agric Food Chem 52: 61226128. DOI: $10.1021 / \mathrm{jf0} 49517 \mathrm{a}$

Hyun JW, Chung HS. 2004. Cyanidin and malvidin from Oryza sativa cv. Heugjinjubyeo mediated cytotoxicity against human monocytic leukemia cells by arrest of $\mathrm{G} 2 / \mathrm{M}$ phase and induction of apoptosis. J Agric Food Chem 52: 2213-2217. DOI: 10.1021/jf030370h

Santika A, Rozakurniati. 2010. Teknik evaluasi mutu beras ketan dan beras merah pada beberapa galur padi gogo. Buletin Teknik Pertanian 15 (1): $1-5$. [Indonesian] 
Departemen Pertanian. 2009a. Pelepasan Padi Gogo Beras Merah Lokal Mandel sebagai Varietas Unggul dengan nama Mandel Handayani. Surat Keputusan Menteri Pertanian Nomor 2227/Kpts/SR.120/5/2009 tanggal 19 Mei 2009. Departemen Pertanian, Jakarta. [Indonesian]

Departemen Pertanian. 2009b. Pelepasan Padi Gogo Beras Merah Lokal Segreng sebagai Varietas Unggul dengan nama Segreng Handayani. Surat Keputusan Menteri Pertanian Nomor 2226/Kpts/SR.120/5/2009 tanggal 19 Mei 2009. Departemen Pertanian, Jakarta. [Indonesian]

Badan Litbang Pertanian. 2012. Padi Unggul Baru. Warta Penelitian Pertanian 34 (1): 8-9. [Indonesian]

Mau YS, Ndiwa AS, Markus JE, Oematan SS, Nasution A, Handoko DD, Makbul K. 2017. Genetic diversity of red and black upland rice accessions from East Nusa Tenggara, Indonesia as revealed by agromorphological characters. Biodiversitas 18 (1): 197-211. DOI 10.13057/biodiv/d180127.

Mau YS, Ndiwa AS, Markus JE, Oematan SS, Nasution A, Handoko DD, Makbul K. 2018. Blast resistance levels of red and black upland rice local cultivars from Indonesia. Asian J Crop Sci 10 (2): 53-65. DOI: 10.3923/ajcs.2018.
Mau YS, Ndiwa AS, Markus JE, Oematan SS. 2019. Drought tolerance indices for selection of drought-tolerant, high-yielding upland rice genotypes. Aust J Crop Sci 10 (3): 170-178. DOI: 10.21475/ajcs.19.13.01.p1778.

Sunihardi, Hermanto D, Adikin, Hikmat E. 2004. Deskripsi Varietas Unggul Padi dan Palawija 2002-2004. Pusat Penelitian dan Pengembangan Tanaman Pangan, Badan Litbang Pertanian, Bogor. [Indonesian]

Suparyono, Setyono A. 1993. Padi. Penebar Swadaya, Jakarta. [Indonesian]

Siregar IZ, Khumaida N, Noviana D, Wibowo HM, Azizah. 2013. Varietas Unggul Tanaman. Institut Pertanian Bogor. Direktorat Riset dan Inovasi, Institut Pertanian Bogor. [Indonesian]

Yoshida S. 1981. Fundamental of Rice Crop Science. Philippines. The International Rice Research and Institute, Los Banos, Laguna, Philippines.

Yan W, Kang MS. 2003. GGE biplot analysis, a graphical tool for breeders, geneticists, and agronomists. Boca Raton, London, CRC Press, New York, Washington D.C. DOI: 10.1201/9781420040371 